\title{
Penerapan Pendekatan Pembelajaran Time Token untuk Meningkatkan Kemampuan Pemecahan Masalah Matematik Siswa di Madrasah Aliyah
}

\author{
Agus Suhendra ${ }^{1, a)}$, Nunung Sobarningsih ${ }^{1}$, dan Wati Susilawati ${ }^{1}$ \\ ${ }^{1}$ Prodi Pendidikan Matematika, UIN Sunan Gunung Djati Bandung, \\ J1. A.H. Nasution No. 105, Bandung 40614, Indonesia \\ ${ }^{a}$ E-mail: pmtk@uinsgd.ac.id
}

\begin{abstract}
Abstrak. Penelitian ini bertujuan untuk mengetahui proses belajar matematika siswa, kemampuan pemecahan masalah matematik siswa pada setiap siklus, kemampuan pemecahan masalah matematik siswa setelah mengikuti seluruh siklus, dan sikap siswa kelas X.1 MAN Tanggeung mengikuti seluruh siklus melalui pendekatan pembelajaran Time Token pada pokok bahasan bentuk akar. Metode penelitian yang digunakan adalah penelitian tindakan kelas (Classroom Action Research) dengan langkah-langkah yang dilakukan dalam penelitian ini berbentuk siklus yaitu: Perencanaan (Planning); Tindakan (Acting); Pengamatan (Observing); Refleksi (Reflecting). Sampel yang digunakan dalam penelitian ini berjumlah 38 orang yang terdiri dari 13 orang laki-laki dan 25 orang perempuan. Instrumen yang digunakan untuk mengumpulkan data dalam penelitian ini terdiri dari lembar observasi aktivitas untuk mengetahui aktivitas siswa dan guru selama proses pembelajaran berlangsung, tes formatif dan post test yang berisi soal-soal matematika tentang bentuk akar, dan untuk melihat sikap siswa terhadap pembelajaran matematika dengan pendekatan pembelajaran Time Token, skala sikap siswa yang dipakai adalah model skala likert dengan teknik penskoran secara aposteriori. Hasil penelitian dapat disimpulkan bahwa oenerapan pembelajaran Time Token efektif untuk meningkatkan kemampuan pemecahan masalah matematik siswa. Disarankan Untuk guru dapat lebih kreatif dan inovatif dalam melatih dan mengembangkan keterampilan sosial siswa agar siswa tidak mendominasi pembicaraan atau diam sama sekali.
\end{abstract}

Kata Kunci. Time Token, Pemecahan Masalah

\section{Pendahuluan}

Pendidikan pada dasarnya merupakan suatu upaya untuk memberikan pengetahuan, wawasan, keterampilan dan keahlian tertentu kepada individu guna mengembangkan bakat serta kepribadian mereka (Khotimah, 2008: 1). Dengan pendidikan manusia berusaha mengembangkan dirinya sehingga mampu menghadapi setiap perubahan yang terjadi akibat adanya kemajuan ilmu pengetahuan dan teknologi. Pendidikan bukanlah suatu hal yang statis atau tetap melainkan suatu hal yang dinamis sehingga menuntut adanya suatu perubahan atau perbaikan secara terus-menerus.

Matematika merupakan salah satu bidang studi yang menduduki peranan penting dalam pendidikan. Hal ini dapat dilihat dari waktu, jam pelajaran sekolah lebih banyak dibandingkan pelajaran lain. Melalui pembelajaran matematika, siswa mendapat kesempatan untuk mengembangkan kemampuan berpikir logis, kritis, analisis, 
kreatif, dan produktif serta mampu memecahkan permasalahan realita kehidupan sehari-hari. Namun, banyak faktor yang menyebabkan pengembangan berbagai kompetensi tersebut belum tercapai secara optimal. Setelah dilakukan penelitian salah satu permasalahan strategis yang dialami siswa adalah kurangnya kemampuan dalam pemecahan masalah matematika. Dalam proses pembelajaran siswa hanya bekerja berdasarkan pada perintah atau tugas-tugas yang diberikan oleh guru. Akibatnya, siswa tidak mampu mengembangkan gaya fikir tingkat tinggi. Hal ini didukung oleh Sumarno (Jihad, 2006) bahwa sebagian besar guru menyajikan materi hanya yang bersifat algoritmis dan kurang menggali kemampuan siswa untuk bernalar.

Polya (Ardiyati, 2006: 13) mengemukakan bahwa pemecahan masalah sebagai usaha mencari jalan keluar dari suatu kesulitan guna mencapai suatu tujuan yang tidak begitu saja dapat dicapai. Selaras dengan itu Cooney menyatakan bahwa pemecahan masalah sebagai proses menerima masalah dan berusaha menyelesaikan masalah tersebut.

Pentingnya kemampuan pemecahan masalah matematika dimiliki oleh siswa dikemukakan oleh Branca (Jihad, 2006) sebagai berikut: (1) kemampuan menyelesaikan merupakan tujuan umum pengajaran matematika, bahkan sebagai jantungnya matematika; (2) penyelesaian masalah meliputi metode, prosedur dan strategi merupakan proses inti dan utama dalam kurikulum matematika; dan (3) penyelesaian matematika merupakan kemampuan dasar dalam belajar matematika.

Realita di lapangan ditemukan bahwa kemampuan pemecahan masalah matematik siswa di beberapa sekolah masih tergolong rendah. Hal tersebut berdasarkan hasil penelitian yang dilakukan The National Assesment of Educational Progres (NAEP) (MKPBM, 2001: 84) bahwa dalam soal pemecahan masalah dengan langkah penyelesaian prestasi kurang begitu baik sekitar 30\% siswa kelas 3 yang berhasil dengan baik menyelesaikan soal pemecahan masalah.

Salah satu upaya untuk menciptakan kemampuan pemecahan masalah matematik adalah dengan pendekatan pembelajaran matematika. Pendekatan (Approach) pembelajaran matematika adalah cara yang ditempuh guru dalam pelaksanaan pembelajaran agar konsep yang disajikan bisa beradaptasi dengan siswa. Ada dua jenis pendekatan dalam pembelajaran matematika, yaitu 
Penerapan Pendekatan Pembelajaran Time Token untuk Meningkatkan kemampuan pemahaman siswa

pendekatan yang bersifat metodologis dan pendekatan yang bersifat material. Pendekatan metodologi berkenaan dengan cara siswa beradaptasi dengan konsep yang disajikan ke dalam struktur kognitifnya, yang sejalan dengan cara guru menyajikan bahan tersebut. Sedangkan pendekatan material yaitu pendekatan pembelajaran matematika dalam menyajikan konsep matematika melalui konsep matematika lain yang telah dimiliki siswa.

Time Token merupakan pendekatan pembelajaran yang bersifat metodologis. Hubungan antara Time Token dengan pemecahan masalah matematik siswa sangat berkaitan. Dalam Time Token siswa dituntut untuk mengemukakan ide, gagasan, pendapat, pertanyaan atau menjawab pertanyaan yang sifatnya wajib. Sehingga semua siswa harus memahami pemecahan masalah yang dihadapi. Dengan demikian, kemampuan pemecahan masalah matematik siswa akan terlatih dan meningkat.

Menurut Arebds, 1998 (Susilawati, 2008) Time Token adalah pendekatan pembelajaran untuk melatih dan mengembangkan keterampilan sosial agar siswa tidak mendominasi pembicaraan atau diam sama sekali. Sehingga siswa tidak lagi menjadi pendengar setia. Siswa akan Jurnal Analisa Vol.1 No.1 Juni 2013 :1-11 mudah berfikir dan langsung bisa mengungkapkan berbagai pemecahan masalah yang dihadapi.

Penelitian yang dilakukan mengambil sub materi bentuk akar. Pengambilan materi tersebut dikarenakan prestasi matematika siswa berada pada level menengah ke bawah bahkan kemampuan pemecahan masalah matematik siswa sangat rendah. Akibatnya masih banyak siswa yang belum memahami permasalahan yang dihadapi, belum mampu merencanakan penyelesaian, belum mahir melakukan perhitungan, dan rata-rata siswa belum bisa memeriksa kembali proses.

Berdasarkan uraian yang disampaikan, peneliti memperkirakan bahwa pembelajaran yang tepat untuk meningkatkan kemampuan pemecahan masalah matematik dalam pokok bahasan bentuk akar adalah dengan pendekatan pembelajaran Time Token. Oleh karena itu, peneliti tertarik untuk melakukan penelitian dengan tujuan untuk mengetahui proses belajar matematika siswa, kemampuan pemecahan masalah matematik siswa pada setiap siklus, kemampuan pemecahan masalah matematik siswa setelah mengikuti seluruh siklus, dan sikap siswa mengikuti seluruh siklus melalui pendekatan pembelajaran 
Time Token. Sehingga dapat dimanfaatkan untuk menambah variasi dalam kegiatan belajar mengajar agar siswa berminat dan termotivasi untuk belajar.

\section{Metodologi Penelitian}

Penelitian dilakukan di kelas X.1 MAN Tanggeung - Cianjur Selatan. Dengan jumlah siswa 38 orang, yang terdiri dari 13 orang laki-laki dan 25 orang perempuan. Metode yang digunakan dalam penelitian ini adalah penelitian tindakan kelas (Classroom Action Research), yang berusaha mengkaji dan merefleksi suatu model pembelajaran dengan tujuan untuk meningkatkan proses dan produk pengajaran di kelas.

Penelitian tindakan kelas melibatkan interaksi, partisipasi, dan kolaborasi antara peneliti dan siswa. Adapun langkahlangkah yang akan dilakukan dalam penelitian ini berbentuk siklus berpedoman pada model yang diadaptasi dari Sudikin dkk (Hartati, 2008: 14) dimana setiap siklus terdiri dari empat komponen

\section{Hasil dan Pembahasan}

Berdasarkan penelitian yang telah dilakukan di MAN Tanggeung diperoleh hasil sebagai berikut:

Berdasarkan hasil analisis observasi diperoleh bahwa aktivitas tiap siswamengalami peningkatan, hal ini dapat kegiatan pokok, yaitu: (1) Perencanaan (Planning); (2) Tindakan (Acting); (3) Pengamatan (Observing); (4) Refleksi (Reflecting). Pada pelaksanaannya ke empat komponen kegiatan pokok itu berlangsung secara terus menerus.

Instrumen yang digunakan untuk mengumpulkan data dalam penelitian ini adalah instrumen observasi digunakan untuk mengetahui proses belajar mengajar matematika yang menggunakan pendekatan pembelajaran Time Token yang meliputi aktivitas siswa dan aktivitas guru selama proses pembelajaran berlangsung, instrumen tes digunakan untuk mengukur kemampuan pemecahan masalah matematik siswa, instrumen skala sikap digunakan untuk mengetahui sikap siswa mengenai pembelajaran dengan pendekatan Time Token. Skala yang digunakan adalah skala likert dengan teknik penskoran secara aposteriori.

Adapun tes yang digunakan dalam penelitian ini adalah jenis tes uraian yang meliputi tes evaluasi siklus dan post tes dilihat dari rata-rata kemampuan pemecahan masalah matematika siswa pada setiap pertemuan. Dari siklus I $(69,61 \%)$ ke siklus II $(71,01 \%)$ Kemudian ke siklus III (71.70\%). Ada peningkatan persentase rata-rata sebesar $1,40 \%$, dari 
Penerapan Pendekatan Pembelajaran Time Token untuk Meningkatkan kemampuan pemahaman siswa

$69,61 \%$ pada siklus I menjadi $71,01 \%$ pada siklus II. Untuk rincian presentase indikator setiap siklus disajikan pada tabel 1.

Tabel 1. Presentase Indikator Pada Tiap Siklus

\begin{tabular}{|c|c|c|c|}
\hline Indikator & Siklus I & Siklus II & Siklus III \\
\hline $\begin{array}{l}\text { Siswa dapat } \\
\text { mengungkapkan ide, } \\
\text { gagasan, bertanya dan } \\
\text { menjawab pertanyaan }\end{array}$ & $62,89 \%$ & $67,36 \%$ & $69,44 \%$ \\
\hline $\begin{array}{lr}\text { Siswa } & \text { dapat } \\
\text { menyelesaikan } & \text { soal- } \\
\text { soal yang ada di } & \text { LKS } \\
\text { secara individu } & \end{array}$ & $79,55 \%$ & $81,94 \%$ & $81,94 \%$ \\
\hline $\begin{array}{lr}\text { Siswa } & \text { dapat } \\
\text { mempersiapkan } & \text { diri } \\
\text { untuk diskusi } & \end{array}$ & $91,67 \%$ & $90,97 \%$ & $91,67 \%$ \\
\hline $\begin{array}{l}\text { Siswa dapat tampil } \\
\text { untuk } \\
\text { mempresentasikan } \\
\text { hasil kerjanya }\end{array}$ & $50,00 \%$ & $50,00 \%$ & $47,92 \%$ \\
\hline $\begin{array}{lr}\text { siswa } & \text { menyimak } \\
\text { masalah } & \text { yang } \\
\text { dibicarakan/ } & \\
\text { diselesaikan } & \end{array}$ & $84,85 \%$ & $88,89 \%$ & $88,89 \%$ \\
\hline $\begin{array}{lr}\text { siswa } & \text { dapat } \\
\text { memecahkan } & \text { masalah } \\
\text { dengan tepat } & \\
\end{array}$ & $47,73 \%$ & $50,00 \%$ & $45,83 \%$ \\
\hline $\begin{array}{ll}\text { siswa menilai dan } \\
\text { memperbaiki } & \\
\text { penyelesaian } & \text { yang } \\
\text { kurang tepat } & \end{array}$ & $56,06 \%$ & $56,25 \%$ & $63,89 \%$ \\
\hline $\begin{array}{lr}\text { siswa } & \text { menjawab } \\
\text { pertanyaan } & \text { yang } \\
\text { diberikan guru } & \text { pada } \\
\text { akhir pelajaran } & \end{array}$ & $84,09 \%$ & $82,64 \%$ & $84,03 \%$ \\
\hline
\end{tabular}

Hal ini menggambarkan bahwa kegiatan pembelajaran sudah mulai bisa diikuti oleh seluruh siswa. Pada siklus III pun ada peningkatan persentasi aktivitas siswa sebesar $0,69 \%$, walaupun peningkatan ini tidak dari semua indikator aktivitas siswa. Tapi hal ini menggambarkan bahwa Jurnal Analisa Vol.1 No.1 Juni 2013 :1-11 kegiatan belajar mengajar bisa diikuti oleh siswa. Secara keseluruhan rata-rata presentase kemampuan pemecahan masalah matematika siswa disajikan pada Tabel 2. Dan gambar 2. 
Table 2 Rata-Rata Persentase Aktivitas Siswa Pada Setiap Siklus

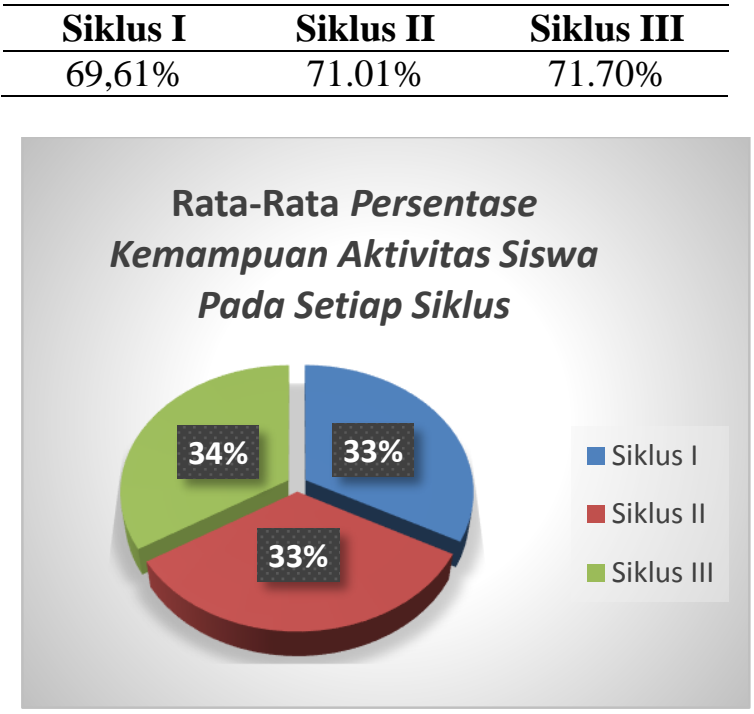

Gambar 2 Grafik Peningkatan Aktivitas Siswa Pada Setiap Siklus

Berdasarkan hasil perhitungan data tes formatif siswa pada setiap siklus mengalami peningkatan, hal ini dapat dilihat dari rata-rata kemampuan pemecahan masalah matematika siswa pada setiap pertemuan. Dari siklus I $(72,40 \%)$ ke siklus II $(78,33 \%)$ Kemudian ke siklus $\operatorname{III}(83,50 \%)$. Kemampuan pemecahan masalah matematik siswa mengalami peningkatan sebesar $11.10 \%$

Kondisi ini menggambarkan bahwa siswa mampu mengikuti proses pembelajaran yang diterapkan oleh guru. Secara keseluruhan rata-rata presentase kemampuan pemecahan masalah matematika siswa disajikan pada Tabel 3. Dan gambar 3.
Table 3 Rata-Rata Persentase Kemampuan Pemecahan Masalah Matematika Siswa Pada Setiap Siklus

\begin{tabular}{ccc}
\hline Siklus I & Siklus II & Siklus III \\
\hline $72,40 \%$ & $78,33 \%$ & $83,50 \%$ \\
\hline
\end{tabular}

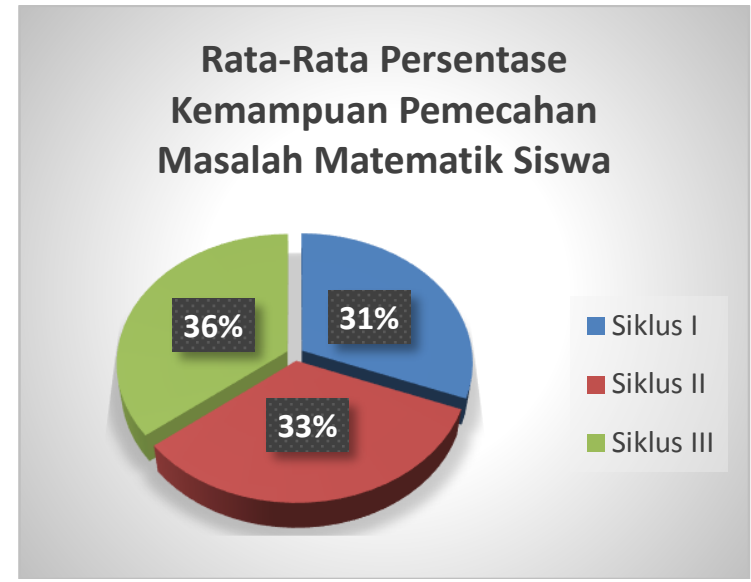

Gambar 3 Grafik Peningkatan

Kemampuan Pemecahan Masalah Matematika Siswa Pada Setiap Siklus

Setelah seluruh siklus pembelajaran berakhir maka dilaksanakan post test untuk mengetahui kemampuan pemecahan masalah matematika siswa pada sub pokok bahasan bentuk akar setelah mengikuti pembelajaran dengan menggunakan pendekatan pembelajaran Time Token.

Adapun kriteria penilaian pemecahan masalah matematika siswa pada post test dapat dilihat pada tabel 4 dan gambar 4 .

Tabel 4 Klasifikasi Pemecahan Masalah Matematika Siswa Pada Post Test

\begin{tabular}{|c|c|l|}
\hline $\begin{array}{c}\text { Klasifikasi } \\
\text { Kemampuan } \\
\begin{array}{c}\text { Pemecahan Masalah } \\
\text { Matematika Siswa }\end{array}\end{array}$ & $\begin{array}{c}\text { Jumlah } \\
\text { Siswa }\end{array}$ & $\begin{array}{c}\text { Kriteria } \\
\text { Penelitian }\end{array}$ \\
\hline A & 5 & Sangat Tinggi \\
\hline B & 22 & Tinggi \\
\hline C & 10 & Cukup \\
\hline D & - & Rendah \\
\hline
\end{tabular}


Penerapan Pendekatan Pembelajaran Time Token untuk Meningkatkan kemampuan pemahaman siswa

\begin{tabular}{|l|l|l|}
\hline E & - & $\begin{array}{l}\text { Sangat } \\
\text { Rendah }\end{array}$ \\
\hline
\end{tabular}

\section{Keterangan:}

$\begin{array}{ll}90 \% \leq \mathrm{A} \leq 100 \% & \text { Sangat Tinggi } \\ 75 \% \leq \mathrm{B}<90 \% & \text { Tinggi } \\ 55 \% \leq \mathrm{C}<75 \% & \text { Cukup } \\ 40 \% \leq \mathrm{D}<55 \% & \text { Rendah } \\ 0 \% \leq \mathrm{E}<40 \% & \text { Sangat Rendah }\end{array}$

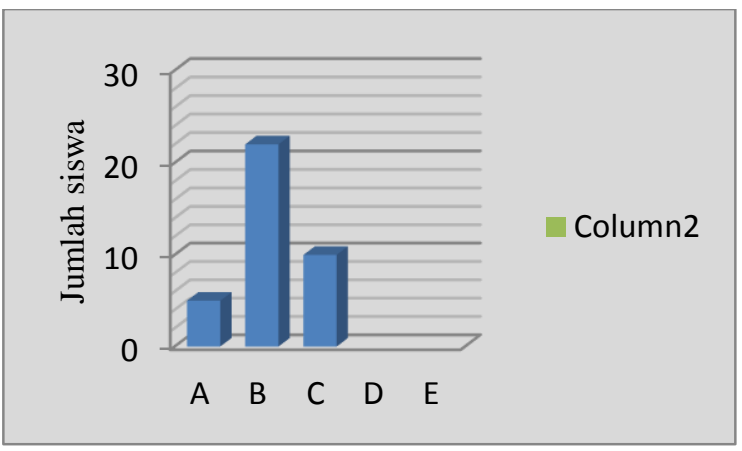

Gambar 4 Grafik Klasifikasi Pemecahan Masalah Matematika Siswa pada post test adapun perkembangan kemampuan pemecahan masalah matematika tiap siswa dapat dilihat dari rata-rata persentase nilai tes formatif tiap siklus yang mengalami peningkatan, walaupun tidak mengalami peningkatan yang signifikan. Hal ini diakibatkan ada sebagian siswa yang tidak hadir dan kurang memperhatikan proses kegiatan pembelajaran. Secara keseluruhan rata-rata persentase hasil tes formatif tiap siklus dan post test disajikan pada Tabel 5 dan Gambar 5.

Tabel 5 Perkembangan Kemampuan Pemecahan Masalah Matematika Siswa

\begin{tabular}{|c|l|c|c|}
\hline No & \multicolumn{1}{|c|}{ Evaluasi } & $\begin{array}{c}\text { Rata-rata Persentase } \\
\text { Kemampuan Pemecahan } \\
\text { Masalah Matematika Siswa } \\
(\%)\end{array}$ & Kriteria \\
\hline 1 & Tes Formatif Siklus I & 72,40 & Tinggi \\
\hline 2 & Tes Formatif Siklus II & 78,33 & Tinggi \\
\hline 3 & Tes Formatif Siklus III & 83,50 & Tinggi \\
\hline 4 & Post Test & 77,50 & Tinggi \\
\hline
\end{tabular}

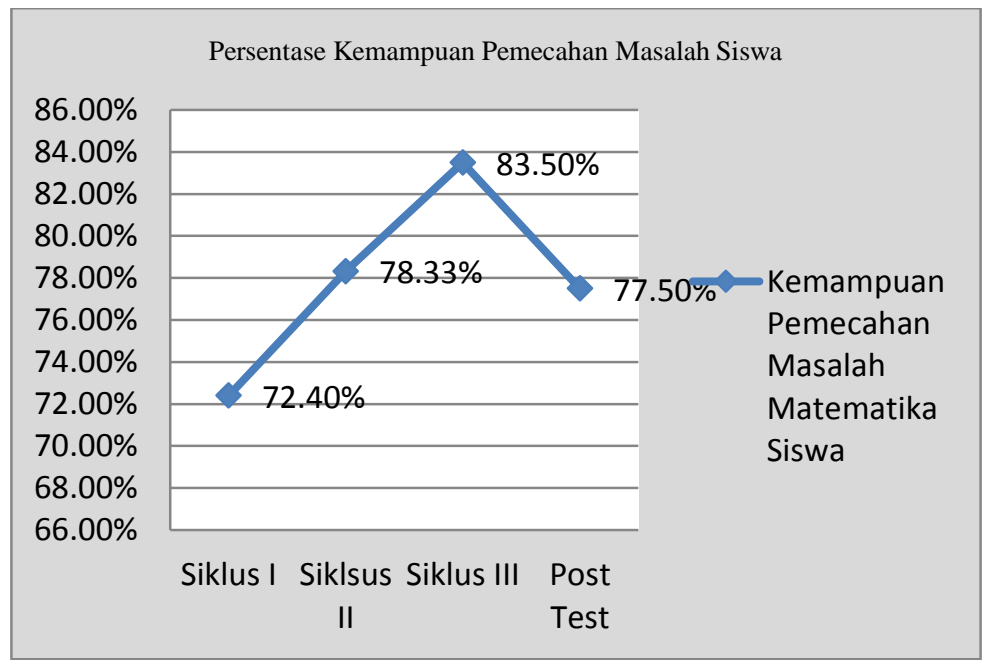

Gambar 5 Grafik Persentase Kemampuan Pemecahan Masalah Siswa 
Tabel 5 dan Gambar 5 memberikan informasi bahwa rata-rata persentase kemampuan pemecahan masalah matematika siswa tiap siklus terjadi peningkatan. Dari siklus I ke siklus II menagalami peningkatan $5,93 \%$ dan dari siklus II ke siklus III mengalami peningkatan $5,17 \%$. Sementara nilai ratarata post test sebesar $77,50 \%$ dengan kriteria penilaian tinggi, ini menurun karena siswa dituntut untuk dapat menguasai materi pelajaran secara keseluruhan dari tiap siklus yang diberikan.

Berdasarkan hasil analisis data skala sikap diketahui bahwa tanggapan siswa terhadap pembelajaran matematika cukup baik. Dari hasil skor sikap siswa yaitu 3,07 dan sikap netral 2,90 dapat menunjukan bahwa siswa memiliki sikap positif terhadap pembelajaran matematika dengan menggunakan Time Token. Hal ini dapat dilihat pada Tabel 6

Tabel 6 Distribusi Skor Siswa Terhadap Pembelajaran Matematika

\begin{tabular}{|c|c|c|c|c|c|c|c|c|c|c|c|}
\hline \multirow[t]{2}{*}{ Sikap } & \multirow[t]{2}{*}{ Indikator } & \multirow{2}{*}{$\begin{array}{l}\text { No } \\
\text { Soal }\end{array}$} & \multirow{2}{*}{$\begin{array}{l}\text { Jenis } \\
\text { Soal }\end{array}$} & \multicolumn{4}{|c|}{ Jawaban } & \multicolumn{2}{|c|}{$\begin{array}{c}\text { Skor Sikap } \\
\text { Siswa }\end{array}$} & \multicolumn{2}{|c|}{ Sikap Netral } \\
\hline & & & & $\mathrm{SS}$ & $\mathrm{S}$ & $\mathrm{TS}$ & STS & Item & Rerata & Item & Rerata \\
\hline \multirow{10}{*}{$\begin{array}{l}\text { Terhadap } \\
\text { pembelajaran } \\
\text { matematika }\end{array}$} & \multirow{2}{*}{$\begin{array}{l}\text { Kesukaan siswa } \\
\text { terhadap mata pelajaran } \\
\text { matematika }\end{array}$} & \multirow[b]{2}{*}{1} & Positif & 1 & 10 & 21 & 4 & \multirow[b]{2}{*}{3,08} & \multirow{10}{*}{3,07} & \multirow[b]{2}{*}{3,00} & \multirow{10}{*}{2,90} \\
\hline & & & Skor & 4 & 4 & 3 & 1 & & & & \\
\hline & \multirow{4}{*}{$\begin{array}{l}\text { Tanggapan siswa } \\
\text { terhadap proses } \\
\text { pembelajaran } \\
\text { matematika di kelas }\end{array}$} & \multirow{2}{*}{2} & Negatif & 4 & 27 & 5 & 0 & \multirow{2}{*}{2,03} & & \multirow{2}{*}{2,75} & \\
\hline & & & Skor & 1 & 2 & 3 & 5 & & & & \\
\hline & & \multirow{2}{*}{3} & Negatif & 0 & 4 & 23 & 9 & \multirow{2}{*}{4,14} & & \multirow{2}{*}{3,25} & \\
\hline & & & Skor & 1 & 3 & 4 & 5 & & & & \\
\hline & \multirow{4}{*}{$\begin{array}{c}\text { Motivasi siswa terhadap } \\
\text { pembelajaran } \\
\text { matematika }\end{array}$} & \multirow{2}{*}{4} & Negatif & 1 & 1 & 26 & 8 & \multirow{2}{*}{3,14} & & \multirow{2}{*}{2,5} & \\
\hline & & & Skor & 1 & 2 & 3 & 4 & & & & \\
\hline & & \multirow{2}{*}{5} & Negatif & 0 & 2 & 34 & 0 & \multirow{2}{*}{2,94} & & \multirow{2}{*}{3,00} & \\
\hline & & & Skor & 1 & 2 & 3 & 6 & & & & \\
\hline
\end{tabular}

Berdasarkan hasil analisis data skala sikap diketahui bahwa tanggapan siswa terhadap soal-soal pemecahan masalah yang diberikan guru menuntut pemecahan masalah matematika siswa baik. Dari hasil skor sikap siswa yaitu 3,23 dan sikap netral 2,90 dapat menunjukan bahwa siswa memiliki sikap positif terhadap soal-soal pemecahan masalah yang diberikan guru guna menuntut kemampuan pemecahan masalah matematika siswa. Hal ini dapat dilihat dari distributor skor siswa yang tertera pada Tabel 7. 
Penerapan Pendekatan Pembelajaran Time Token untuk Meningkatkan kemampuan pemahaman siswa

Tabel 7 Distribusi Skor Siswa Terhadap Soal-soal pemecahan masalah matematika

\begin{tabular}{|c|c|c|c|c|c|c|c|c|c|c|c|}
\hline \multirow[t]{2}{*}{ Sikap } & \multirow[t]{2}{*}{ Indikator } & \multirow{2}{*}{$\begin{array}{l}\text { No } \\
\text { Soal }\end{array}$} & \multirow{2}{*}{$\begin{array}{l}\text { Jenis } \\
\text { Soal }\end{array}$} & \multicolumn{4}{|c|}{ Jawaban } & \multicolumn{2}{|c|}{$\begin{array}{c}\text { Skor Sikap } \\
\text { Siswa }\end{array}$} & \multicolumn{2}{|c|}{ Sikap Netral } \\
\hline & & & & SS & $\mathrm{S}$ & TS & STS & Item & Rerata & Item & Rerata \\
\hline \multirow{10}{*}{$\begin{array}{l}\text { Terhadap } \\
\text { soal-soal } \\
\text { pemecahan } \\
\text { masalah } \\
\text { matematik }\end{array}$} & \multirow{4}{*}{$\begin{array}{l}\text { Tanggapan siswa } \\
\text { terhadap soal-soal } \\
\text { pemecahan masalah } \\
\text { matematik }\end{array}$} & \multirow{2}{*}{6} & Positif & 3 & 13 & 17 & 3 & \multirow{2}{*}{2,53} & \multirow{10}{*}{3,23} & \multirow{2}{*}{2,75} & \multirow{10}{*}{2,90} \\
\hline & & & Skor & 5 & 3 & 2 & 1 & & & & \\
\hline & & \multirow[t]{2}{*}{7} & $\begin{array}{l}\text { Negati } \\
\quad \mathrm{f}\end{array}$ & 0 & 14 & 20 & 2 & \multirow[t]{2}{*}{2,61} & & \multirow[t]{2}{*}{2,25} & \\
\hline & & & Skor & 1 & 2 & 3 & 3 & & & & \\
\hline & \multirow{4}{*}{$\begin{array}{l}\text { Manfaat } \\
\text { mengerjakan soal- } \\
\text { soal pemecahan } \\
\text { masalah matematik. }\end{array}$} & \multirow{2}{*}{9} & Positif & 3 & 23 & 10 & 0 & \multirow{2}{*}{3,81} & & \multirow{2}{*}{3,25} & \\
\hline & & & Skor & 5 & 4 & 3 & 1 & & & & \\
\hline & & \multirow[b]{2}{*}{10} & Positif & 11 & 25 & 0 & 0 & \multirow[b]{2}{*}{3,61} & & \multirow[b]{2}{*}{2,75} & \\
\hline & & & Skor & 5 & 3 & 2 & 1 & & & & \\
\hline & \multirow{2}{*}{$\begin{array}{l}\text { Menunjukkan } \\
\text { Semangat dalam } \\
\text { mengerjakan soal- } \\
\text { soal pemecahan } \\
\text { masalah matematik }\end{array}$} & \multirow[b]{2}{*}{8} & Positif & 0 & 25 & 9 & 2 & \multirow[b]{2}{*}{3,58} & & \multirow{2}{*}{3,50} & \\
\hline & & & Skor & 6 & 4 & 3 & 1 & & & & \\
\hline
\end{tabular}

Berdasarkan hasil analisis data skala sikap (Lampiran A halaman 123) diketahui bahwa tanggapan siswa terhadap pembelajaran matematika dengan menggunakan pendekatan pembelajaran Time Token cukup baik. Dari hasil skor sikap siswa yaitu 2,95 dan sikap netral 2,93 dapat menunjukan bahwa siswa memiliki sikap positif terhadap pembelajaran matematika dengan menggunakan pendekatan pembelajaran Time Token. Hal ini dapat dilihat dari distributor skor siswa yang tertera pada Tabel 8.

Table 8 Distribusi Skor Sikap Siswa terhadap Pembelajaran Matematika Dengan Menggunakan Pendekatan Pembelajaran Time Token

\begin{tabular}{|c|c|c|c|c|c|c|c|c|c|c|c|}
\hline \multirow{2}{*}{ Sikap } & \multirow{2}{*}{ Indikator } & \multirow{2}{*}{$\begin{array}{l}\text { No } \\
\text { Soal }\end{array}$} & \multirow{2}{*}{$\begin{array}{l}\text { Jenis } \\
\text { Soal }\end{array}$} & \multicolumn{4}{|c|}{ Jawaban } & \multicolumn{2}{|c|}{$\begin{array}{c}\text { Skor Sikap } \\
\text { Siswa }\end{array}$} & \multicolumn{2}{|c|}{ Sikap Netral } \\
\hline & & & & SS & $S$ & $\mathrm{TS}$ & STS & Item & $\begin{array}{c}\text { Rerat } \\
\text { a }\end{array}$ & Item & Rerata \\
\hline \multirow{10}{*}{$\begin{array}{l}\text { Terhadap } \\
\text { pemebelajaran } \\
\text { matematika } \\
\text { dengan } \\
\text { menggunakan } \\
\text { pendekatan } \\
\text { pembelajaran } \\
\text { Time Token }\end{array}$} & \multirow{4}{*}{$\begin{array}{l}\text { Kesukaan siswa terhadap } \\
\text { pembelajaran matematika } \\
\text { melalui } \\
\text { pendekatan pemerapan } \\
\text { Time Token }\end{array}$} & \multirow{2}{*}{13} & Positif & 1 & 25 & 5 & 5 & \multirow{2}{*}{2,67} & \multirow{10}{*}{2,95} & \multirow{2}{*}{3,00} & \multirow{10}{*}{2,93} \\
\hline & & & Skor & 6 & 3 & 2 & 1 & & & & \\
\hline & & \multirow[b]{2}{*}{16} & Positif & 3 & 21 & 7 & 4 & \multirow[b]{2}{*}{2,67} & & \multirow[b]{2}{*}{2,75} & \\
\hline & & & Skor & 5 & 3 & 2 & 1 & & & & \\
\hline & \multirow{6}{*}{$\begin{array}{l}\text { Tanggapan siswa terhadap } \\
\text { pembelajaran matematika } \\
\text { melalui } \\
\text { pendekatan penerapan } \\
\text { Time Token }\end{array}$} & \multirow{2}{*}{14} & Positif & 9 & 18 & 5 & 4 & \multirow{2}{*}{3,64} & & \multirow{2}{*}{3,00} & \\
\hline & & & Skor & 5 & 4 & 2 & 1 & & & & \\
\hline & & \multirow{2}{*}{15} & Positif & 9 & 27 & 0 & 0 & \multirow{2}{*}{4,25} & & \multirow{2}{*}{3,25} & \\
\hline & & & Skor & 5 & 4 & 3 & 1 & & & & \\
\hline & & \multirow{2}{*}{17} & Positif & 0 & 3 & 23 & 10 & \multirow{2}{*}{1,8} & & \multirow{2}{*}{2,5} & \\
\hline & & & Skor & 4 & 3 & 2 & 1 & & & & \\
\hline
\end{tabular}




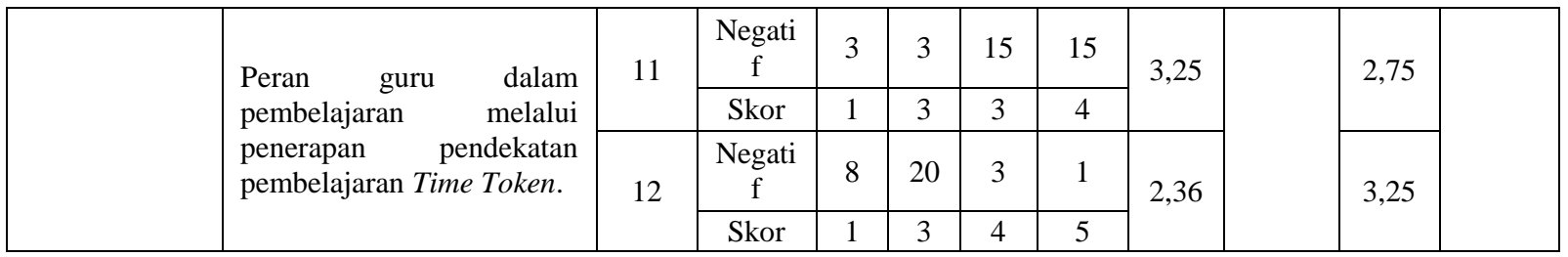

Berdasarkan hasil analisis data skala sikap, diperoleh bahwa sikap siswa terhadap pendekatan pembelajaran Time Token dan terhadap pemecahan masalah matematika cukup baik. Hal ini terlihat dari rata-rata skor sikap siswa yang selalu lebih besar daripada sikap netral siswa, sehingga dapat disimpulkan bahwa siswa merasa sengang mengikuti pembelajaran matematika dengan pendekatan pembelajaran Time Token dan tertarik memecahkan permasalahan matematika yang berhubungan dengan masalah sehari-hari.

\section{Simpulan dan Saran}

Berdasarkan hasil pembahasan yang telah diuraikan, maka dapat disimpulkan: (1) Proses belajar matematika siswa yang memperoleh pendekatan pembelajaran Time Token berjalan sesuai dengan yang diharapkan. Proses pembelajaran mengalami peningkatan. Dari hasil analisis lembar observasi diperoleh bahwa aktivitas siswa mengalami peningkatan pada tiap siklusnya. Sedangkan aktivitas guru selama proses pembelajaran selalu berpijak pada tahapan-tahapan pembelajaran yang telah direncanakan. (2) Kemampuan pemecahan masalah matematika siswa pada tiap siklus melalui pendekatan pembelajaran Time Token mengalami peningkatan.

berdasarkan hasil analisis post test bahwa kemampuan pemecahan masalah matematik siswa setelah diterapkan pendekatan Time Token termasuk kriteria penilaian tinggi (4) Dari hasil analisis lembar skala sikap diperoleh bahwa tanggapan siswa terhadap pembelajaran matematika melalui pendekatan pembelajaran Time Token cukup baik.

Untuk itu guru diharapkan dapat lebih kreatif dan inovatif dalam melatih dan mengembangkan keterampilan sosial siswa agar siswa tidak mendominasi pembicaraan atau diam sama sekali.

\section{Daftar Pustaka}

Arikunto, S. (2005). Dasar-dasar Evaluasi Pendidikan (Edisi Revisi). Jakarta: Bumi Aksara.

Jihad, A. (2006). Meningkatkan

Kemampuan Pemecahan Masalah

Matematik Siswa dengan Metode

IMPROVE Disertai Pemberian

Embedded Test. Bandung: Tesis UPI. 
Lie, A. (2008). Cooperative Learning

(Mempraktikan Cooperative

Learning di Ruang-ruang Kelas).

Jakarta: Grasindo.

Muslich, M. (2007). KTSP Pembelajaran

Berbasis Kompetensi dan

Kontekstual. Jakarta: Bumi Aksara.

Simangunsong, W. (2005). PKS

Matematika Kelas X Sekolah

Menengah Atas dan Madrasah

Aliyah. Jakarta Timur: Gematama.

Sucipto, \& Noormandiri. (2004). Buku

Pelajaran Matematika SMA untuk

Kelas X. Jakarta: Erlangga.

Suherman, \& Sukjaya. (1990). Petunjuk

Praktis untuk Melaksanakan Evaluasi

Pendidikan Matematika. Bandung:

Wijaya Kusuma. 